\title{
ヘモグロビンの生理活性ガス運搬能を利用した創薬戦略
}

\author{
田口和明, ${ }^{*, a, b}$ 松元一明, ${ }^{a}$ 丸山 徹, ${ }^{c}$ 小田切優樹 $b, d$
}

\section{Strategy of Drug Development Based on the Bioactive Gas-carrying Capacity of Hemoglobin}

\author{
Kazuaki Taguchi, ${ }^{*, a, b}$ Kazuaki Matsumoto, ${ }^{a}$ Toru Maruyama, ${ }^{c}$ and Masaki Otagiri ${ }^{b, d}$ \\ ${ }^{a}$ Faculty of Pharmacy, Keio University; 1-5-30 Shibakoen, Minato-ku, Tokyo 105-8512, Japan: ${ }^{b}$ Faculty of Pharmaceutical \\ Sciences, Sojo University; 4-22-1 Ikeda, Nishi-ku, Kumamoto 860-0082, Japan: ' ${ }^{G}$ raduate School of Pharmaceutical \\ Sciences, Kumamoto University; 5-1 Oe-honmachi, Chuo-ku, Kumamoto 862-0973, Japan: and ${ }^{d} D D S$ Research \\ Institute, Sojo University; 4-22-1 Ikeda, Nishi-ku, Kumamoto 860-0082, Japan.
}

(Received July 29, 2019)

\begin{abstract}
Bioactive gas molecules, including oxygen, nitric oxide and carbon monoxide (CO), exhibit a variety of physiological activities, and are associated with the onset and progress of some disorders. These facts have led researchers to the development of bioactive gas donors for the treatment of intractable disorders. Hemoglobin is likely an ideal carrier of bioactive gases, since hemoglobin in red blood cells innately carries oxygen in the form of oxyhemoglobin, nitric oxide in the form of $S$-nitrosohemoglobin, and CO in the form of carbonylhemoglobin. In this study, we attempted to develop a biomimetic $\mathrm{CO}$ delivery system using a preparation of hemoglobin. Our strategy for the preparation of this hemoglobinbased $\mathrm{CO}$ carrier involves $\mathrm{CO}$ being exogenously bound to red blood cells or hemoglobin-encapsulated liposomes, called hemoglobin-vesicles $(\mathrm{HbV})$, which mimic the structure and function of red blood cells. We accumulated evidence that the $\mathrm{CO}$ donors - $\mathrm{CO}$-bound red blood cells and $\mathrm{CO}$-bound $\mathrm{HbV}$ - showed therapeutic efficacy against intractable disorders in animal models. Here, we describe the potential of hemoglobin-based CO donors, especially CO-bound red blood cells and $\mathrm{CO}-$ bound $\mathrm{HbV}$, for the treatment of certain disorders. Hemoglobin-based strategies for the delivery of other bioactive gases for novel drug development are also discussed.
\end{abstract}

Key words — - hemoglobin; red blood cell; liposome; carbon monoxide; heme

\section{1. はじめに}

ヘモグロビンは 2 つの $\alpha$ サブユニットと 2 つの $\beta$ サブユニットから構成される四量体構造を有してお り，各サブユニットにはへムを 1 つずつ有してい る. 通常, 生体内のほとんどのへモグロビンは赤血 球 (red blood cell; RBC) 中に存在し, 主に酸素運 搬の役割を担っている，そのため，へモグロビン製 剂である RBC は大量出血などの重篤な貧血状態時 に，全身の酸素供給不足の是正を目的に臨床現場で 用いられている。.また，へモグロビンは生体内で一 酸化炭素 (carbon monoxide; CO) の内因性のリザー

a慶應義塾大学薬学部（广105-8512 東京都港区芝公園 1-5-30), $b$ 崇城大学薬学部 ( $\bar{T} 860-0082$ 熊本市西区池 田 4-22-1), c熊本大学大学院生命科学研究部 (T8620973 熊本市中央区大江本町 5-1), d崇城大学 DDS 研 究所 (广860-0082 熊本市西区池田 4-22-1)

*e-mail: taguchi-kz@pha.keio.ac.jp 本総説は, 日本薬学会第 139 年会シンポジウム S08 で 発表した内容を中心に記述したものである.
バーでありキャリアとしての役割も担っている. ${ }^{1)}$ つまり，生体内でへムが代謝される過程において産 生された内因性の CO は, RBC 中のへモグロビン と可逆的な結合を示すカルボニルヘモグロビンを形 成し体内を循環した後に，ガス分圧に依存して放出 される (Fig. 1)。この放出された CO は抗酸化・ 抗炎症・シグナル伝達などの多彩な生理活性を示 し, ${ }^{2)}$ 生理活性ガスとして病態生理学上で重要なガ ス状メディエーターとして機能している. 近年, こ の CO の多岐に渡る生理活性が注目され，CO を医 療ガスとして疾患の予防又は治療に臨床応用するた めに，世界中で CO 供与体の開発が積極的に行われ ている.3)

われわれは，CO の創薬を目指した CO 供与体開 発戦略として内因性の CO とへモグロビンが相互作 用する事実を利用した CO デリバリーシステムの構 築を行っている. 具体的には，外因的に $\mathrm{CO}$ を結合 させた $\mathrm{CO}$ 結合型 $\mathrm{RBC}$ (CO-RBC) 又はへモグロ 
(a)

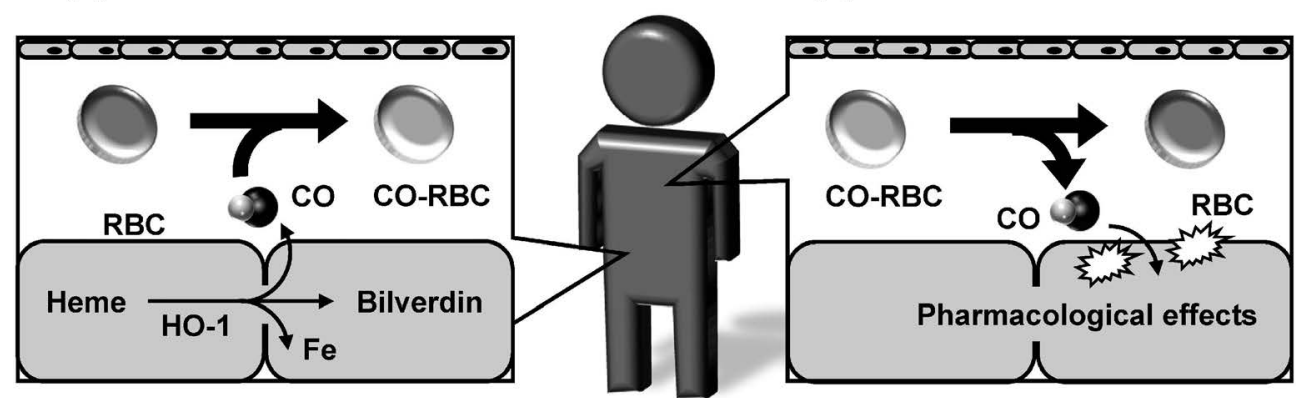

Fig. 1. Systemic Circulation of Endogenous Carbon Monoxide (CO) by Red Blood Cells (RBC)

(a) Endogenous $\mathrm{CO}$, which is produced in the process of heme metabolism by heme oxygenase (HO-1), binds to hemoglobin in RBC and circulates in the body in the form of CO-bound $\mathrm{RBC}(\mathrm{CO}-\mathrm{RBC})$. (b) CO-RBC releases $\mathrm{CO}$ depending on the local partial pressures of both $\mathrm{CO}$ and oxygen.

(a) CO-bound RBC (CO-RBC)

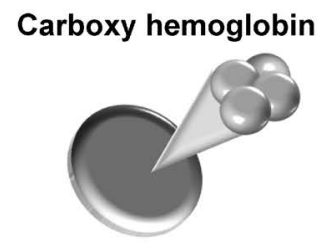

Washed RBC (b) CO-bound HbV (CO-HbV)

\section{Carboxy hemoglobin}

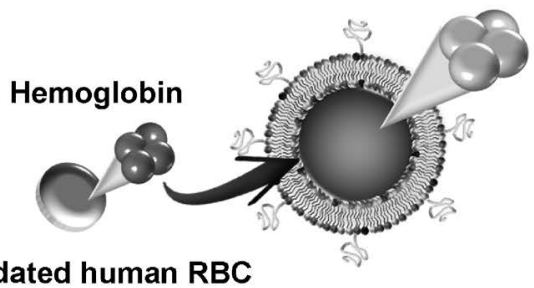

Fig. 2. Schematic Representation of (a) Carbon Monoxide-bound Red Blood Cell (CO-RBC) and (b) Carbon Monoxide-bound Hemoglobin-vesicle (CO-HbV)

ビンを高濃度に内封したリポソーム製剤であるへモ グロビン小胞体 (hemoglobin-vesicle; HbV) にCO

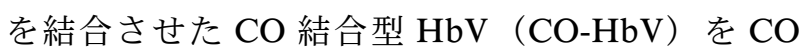
供与体として用い，疾患治療薬としての可能性を探 求している (Fig. 2)。本稿では，われわれがこれ までに難治性疾患モデル動物を用いて明らかにして きた CO-RBC 及び CO-HbV の CO 供与体としての 有用性とへモグロビンを基盤とした生理活性ガスの 創薬戦略について紹介する.

\section{CO-RBC の新規蘇生剂としての有用性評価 ${ }^{4)}$}

外傷, 外科的手術時, 消化管出血などが原因で引 き起こされる大量出血時には，循環血液量の著しい 減少に伴い，全身性の低酸素組織障害である出血性 ショックが誘発され，その対症療法として RBC 輸 血が施行される， RBC 輸血は優れた蘇生効果を発 揮する一方で, 虚血組織へ大量の酸素を急激に供給 する結果，活性酸素種の産生を六進し，虚血再灌流 傷害を助長することが問題視されている.5) われわ れは, 臓器移植に伴う虚血再灌流傷害を $\mathrm{CO}$ が抑制 する報告に着目し, $\left.{ }^{6}\right)$ 大量出血時に CO を担持した
CO-RBC で輸血することで，大量出血に伴う虚血 再灌流傷害が軽減されると考えた，好都合なことに， $\mathrm{CO}-\mathrm{RBC}$ は $\mathrm{CO}$ 放出後に通常の $\mathrm{RBC}$ 製剤と同様に 酸素を運搬するため, 出血性ショック状態からの蘇 生効果も期待できる.

まず， $40 \%$ 出血性ショックモデルラットを RBC 又は CO-RBC で蘇生して, 出血性ショック状態か らの蘇生効果を評価した。その結果，非蘇生群では 脱血開始後 1 時間以内に全例死亡したのに対し, CO-RBC 蘇生群では RBC 蘇生群と同様に, 蘇生 24 時間後（エンドポイント）まで全例が生存した. また, 脱血後には乳酸アシドーシスによる血液 $\mathrm{pH}$ の低下，Base Excess の低下，乳酸值の上昇が認め られたが，いずれのパラメータも RBC あるいは $\mathrm{CO}-\mathrm{RBC}$ 投与 1 時間後には脱血前の值に回復し た。このことは，CO-RBC は CO 放出後に酸素を 運搬し，組織の低酸素状態を改善していることを裏 付けている. 次に, 大量出血後の $\mathrm{RBC}$ 又は CO$\mathrm{RBC}$ 蘇生後の虚血再灌流傷害を, 大量出血後の蘇 生剂投与により最も傷害を受け易い臓器の 1 つであ 
る肝臓に焦点を絞つて検討した。 その結果, 肝機能 を反映するアスパラギン酸アミノトランスフェラー ゼ (aspartate aminotransferase; AST)，アラニンア ミノトランスフェラーゼ (alanine aminotransferase; $\mathrm{ALT})$ は， RBC 蘇生群で顕著な上昇がみられたの に対して, CO-RBC 蘇生群では, これら肝機能パ ラメータの上昇は認められなかつた。これらの結果 から，CO-RBC は大量出血に対する蘇生効果と輸 血後の虚血再灌流傷害を抑制する効果を兼ね備えた 新たな蘇生液としての可能性を提示できた.

肝虚血再灌流時には肝臓中遊離へム鉄濃度が上昇 することが報告されている. ${ }^{7)}$ 遊離へム鉄は過酸化 水素と反応し， 3 価鉄になる結果，強力なヒドロキ シラジカルを生成（フェントン反応）し，血管壁や 細胞の脂質膜の酸化障害を引き起こす. $\left.{ }^{8}\right)$ また, 輸 血に伴う肝虚血再灌流時にはチトクローム P450 （CYP）の発現量が低下することが報告されてお り, 9) 遊離へム鉄の産生源と目される。一方，移植 後の再灌流時において CO 処理することで CYP 含 量の変動が抑制されること, ${ }^{10)}$ が報告されている.

これらの事実より，われわれは CO-RBC 輸血は肝 CYP を保護することで遊離へム鉄濃度の上昇を抑 制し，肝臓の酸化障害を抑制していると仮説を立て た.この仮説を実証すべく, 蘇生後 1 時間における 肝組織中の酸化ストレスマーカー（ヒドロペルオキ シド, マロンジアルデヒド）の産生量を比較した。 その結果, $\mathrm{RBC}$ 蘇生群と比較して CO-RBC 蘇生群 で有意にこれらの酸化ストレスマーカーの産生を抑 制していた。 そこで活性酸素の根源と目される肝臓 中遊離へム鉄量と肝 CYP 発現量を測定したところ, $\mathrm{RBC}$ 蘇生時には既報と同様に肝臓中遊離へム鉄の 増加と肝 CYP 含量が低下していたが，CO-RBC 蘇 生時はこれらの変動を有意に抑制していた。さら に，肝遊離へム鉄量と ALT，マロンジアルデヒド 及び肝 CYP 量との関係性を調べたところ, 遊離へ ム鉄濃度は ALT $(\mathrm{r}=0.97)$, マロンジアルデヒド $(\mathrm{r}=0.89)$ は有意な正の相関性を示し，逆に，総 CYP 量 $(r=0.73)$ とは負の相関性を示した。 以上 の結果より, 大量出血後の CO-RBC 蘇生は肝 CYP の分解を抑制することで遊離へム鉄濃度の上昇を抑 え, 肝虚血再灌流傷害を抑制している可能性が示唆 された。また，年会発表では紹介しなかったが, CO-RBC 蘇生時には Kupffer 細胞の活性化が抑制さ
れ, Kupffer 細胞由来の活性酸素産生量や TLR-4 シ グナルを介した炎症性サイトカインの産生量が減少

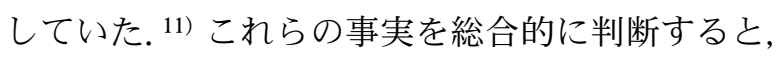
CO-RBC 輸血は CYP の安定化や Kupffer 細胞の活 性化を抑制による抗酸化・抗炎症作用を示し，包括 的に肝虚血再灌流傷害を抑制していると考えられ た。この CO-RBC の CYP 保護効果は, 虚血再灌 流傷害を軽減するだけでなく, 輸血時に併用使用さ れる CYP 代謝型薬物（麻酔薬や鎮痛剂など）の体 内動態や薬理効果の維持にも貢献するため, ${ }^{12)}$ 大量 出血時における CO-RBC 蘇生は併用薬の安定かつ 適切な治療も期待でき, RBC に替わる蘇生剤とし ての優位性も備えていると考えている.

\section{CO-HbV の特発性肺線維症に対する治療効} 果 ${ }^{13)}$

CO-RBC は理想的な CO 供与体である一方で, 現代の輸血システムでは，RBCへのウイルス混入 の可能性などの安全性の面で不安が残される。ま た，日本赤十字社のシミュレーションによると日本 の将来人口の減少と少子高齢化社会により今後, 献 血可能人口が減少し，2027 年には 85 万人以上の献 血者分の血液量が不足すると推定されている. そこ でわれわれは，バイオミメティクスの概念の下，人 工赤血球製剂として開発が進められている $\mathrm{HbV}$ を $\mathrm{RBC}$ に替わる新たな $\mathrm{CO}$ キャリアとして利用する 着想に至った， HbV は，ヒト RBC 由来の精製へモ グロビンをリン脂質二重膜で内包した直径約 $280 \mathrm{~nm}$ の均一なリポソーム製剤であり，その構造 と機能は RBC と同等である. ${ }^{14)} \mathrm{HbV}$ に内封されて いるへモグロビンは，ヒト RBC からへモグロビン を精製する段階においてウイルスを完全に除去して いるため高い安全性が担保されている上に, ${ }^{14)}$ ポリ エチレングリコールを粒子表面へ導入することによ り, $\mathrm{HbV}$ 粒子間の凝集抑制と分散安定性を向上さ せ, 溶液状態で 2 年以上の室温保存が可能であ る. ${ }^{15)} \mathrm{RBC}$ と同様の機能を備えた $\mathrm{HbV}$ は, $\mathrm{CO}$ と 可逆的な結合性を示すとともに, $\mathrm{HbV}$ に CO を外 因的に担持させた CO-HbV を大量投与した場合に おいても，CO に由来する毒性を示さないことも実 証しており, ${ }^{16)} \mathrm{CO}-\mathrm{HbV}$ は CO 供与体として疾患治 療への応用使用が期待できる.

$\mathrm{CO}-\mathrm{HbV}$ の $\mathrm{CO}$ 供与体としての可能性を探究す べく,われわれは CO-HbV の治療対象疾患候補と 
(a)

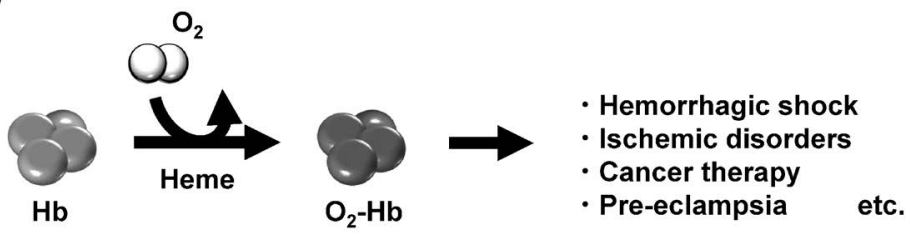

(b)

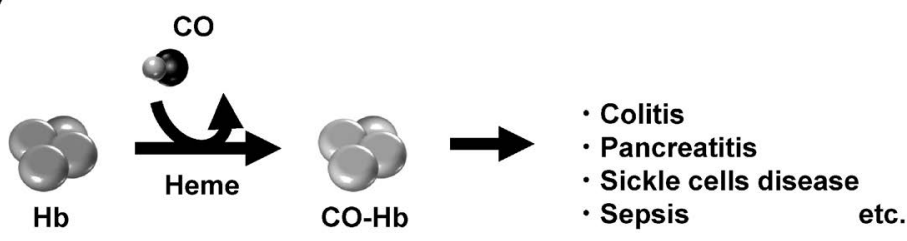

(c)

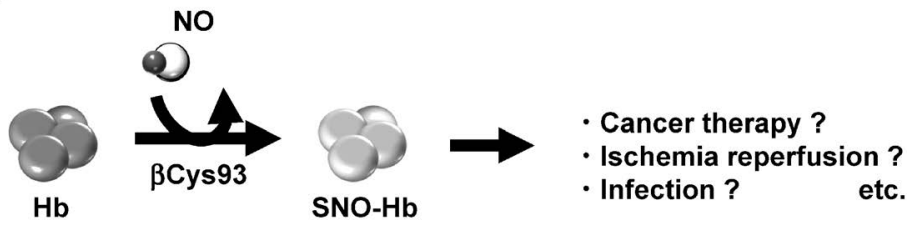

Fig. 3. Potential Applications of Hemoglobin as (a) an Oxygen $\left(\mathrm{O}_{2}\right)$ Carrier, (b) a CO Carrier, and (c) a Nitric Oxide (NO) Carrier

して特発性肺線維症（idiopathic pulmonary fibrosis; IPF）に着目した。IPF は，原因不明の肺線維症で あり，慢性かつ進行性の経過をたどり，最終的には 死に至る予後不良な難治疾患である。 その発症機序 の詳細は明らかになっていないが，IPF 患者におい て還元型ニコチンアミドアデニンジヌクレオチドリ ン酸オキシダーゼ 4 (nicotinamide adenine dinucleotide phosphate oxidase 4; NOX4）の発現が上昇して いること, ${ }^{17)}$ NOX4 欠損マウスにおいて IPF の進行 が抑制されることが報告されており, ${ }^{18)} \mathrm{NOX} 4$ が IPF の発症と進展に関与していると考えられている. NOX4 の活性中心に位置するへム鉄を介して産生 される活性酸素は諸種の疾患の発症・進展に寄与す るため，われわれはへム鉄と高い親和性を有する CO は NOX4 からの活性酸素の産生を抑制するこ とで IPF の発症と進展を抑制すると考えた。そこ で，IPF モデルとして汎用されているブレオマイシ ン誘発 IPF モデルマウスを用いて CO-HbV の IPF に対する治療効果について検討を行つた。まず, $\mathrm{CO}-\mathrm{HbV}$ の肺の線維化に対する影響を線維化評価 として汎用されている肺組織の Masson's trichrome 染色と肺ヒドロキシプロリン含量により評価した. その結果, $\mathrm{HbV}$ 投与群と比較して CO-HbV 投与群 は顕著に肺線維化を抑制していた。さらに，高性能 呼吸機能解析システムを用い肺機能についても検討
したところ，HbV 投与群では線維化の進行に伴い 努力肺活量（forced vital capacity；FVC）の低下が 確認されたが，CO-HbV 投与群では FVCが維持さ れており，CO-HbV は IPF に対して治療効果を有 することが明らかとなつた。

続いて，CO-HbV の IPF 治療メカニズムについ て，上述した NOX4 の活性酸素の産生に着目して 評価した。 NOX4 が活性化すると，それに比例し てスーパーオキシドアニオンの産生量が増大するた め，スーパーオキシドアニオンに特異的なプローブ であるジヒドロエチジウムを用いて肺組織中のスー パーオキシドアニオン産生量を評価した。その結 果，生理食塩水投与群と $\mathrm{HbV}$ 投与群では顕著なジ ヒドロエチジウムの蛍光が観察されたが，CO-HbV 投与群では蛍光強度が低下していた。この CO$\mathrm{HbV}$ による NOX4 由来のスーパーオキシドアニオ ン産生量の低下は，（i）肺における NOX4 発現量の 低下，又は (ii) NOX4 活性の抑制，のいずれかに起 因すると考えられる。そこで，NOX4 の発現量を Western blotting で比較したところ，生理食塩水投 与群， $\mathrm{HbV}$ 投与群，CO-HbV 投与群の間で NOX4 発現量の違いはなかった。また，NOX4 の活性機 構として, 近年, p22phox と Poldip2 が NOX4 と 複合体を形成することで NOX4 の活性化を制御す る重要なレギュレーターであることが明らかとなつ 


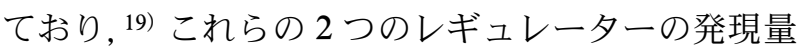
を検討した。 その結果，生理食塩水投与群， $\mathrm{HbV}$ 投与群, $\mathrm{CO}-\mathrm{HbV}$ 投与群の間で p22phox 及び Poldip2 の発現量の変動が認められなかつた。つまり, $\mathrm{CO}-\mathrm{HbV}$ 由来の $\mathrm{CO}$ は, $\mathrm{NOX} 4, \mathrm{p} 22 \mathrm{phox}$, Poldip2 のいずれのタンパク発現量には影響を及ぼさ ず，スーパーオキシドアニオンの産生を抑制してい た。これらの結果は，CO-HbVが NOX4 のへム鉄 に直接作用することで NOX4 からスーパーオキシ ドアニオンの産生を軽減し，IPF の発症と進展を抑 制していると考えられた。

\section{4. ヘモグロビンを基盤とした創薬の現状と今後} の展望

過去半世紀において，HbV を始めとしたへモグ ロビンを修飾又は加工した人工酸素運搬体（人工血 液）の研究開発が世界中で展開され, 20-22) 南アフリ 力の一部の地域に限られるが実際に人工血液 (hemoglobin-based oxygen carrier-201; HBOC-201) がの臨床使用されている. ${ }^{23)}$ また，これらの人工血 液は，本来の開発目的である赤血球代替物としての 使用（貧血の改善）に留まらず，粒子径の小ささか ら赤血球では酸素運搬が困難な心筋梗塞や脳梗塞な

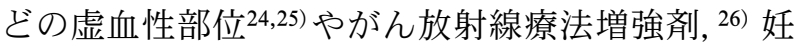
娠高血圧時の胎児の低酸素症改善27)などの酸素送達 剂としての応用使用も期待されている [Fig. 3 (a)］.さらに，本誌で紹介したようにへモグロビン を基盤とした $\mathrm{CO}$ 供与体開発も行われている $[\mathrm{Fig}$. 3(b) ]。われわれは，特発性肺線維症のほかにも $\mathrm{CO}-\mathrm{HbV}$ が潰瘍性大腸炎, ${ }^{28)}$ 急性膵炎, ${ }^{29)}$ 多臓器不 全 ${ }^{30)}$ の治療薬候補になることも見い出している．近 年では，ポリエチレングリコール修飾へモグロビン にCO を結合させた SANGUINATE ${ }^{\mathrm{TM}}$ の臨床試験 が行われている. ${ }^{31,32)}$ また，一酸化窒素がへモグロ ビンのグロビンタンパク部位（ $\beta$ Cys93）に結合し た $S$-ニトロシル化へモグロビンが生体内で検出さ れている. 33) 今後, $S$-ニトロシル化へモグロビンも 生体システムを模倣した生理活性ガスデリバリーシ ステムとして期待できるかもしれない [Fig. 3 (c)]。このように, へモグロビンは, 酸素, CO, 一酸化窒素などのガス状メディエーターの放出制御 担体の優れた創薬素材であり，今後，更なる研究成 果の蓄積によりへモグロビンと医療ガスを融合した 革新的な製剤が開発されることを期待したい.
謝辞 本研究は, 熊本大学薬学部薬剂学研究室 及び崇城大学薬学部薬物動態学研究室で行われたも のであり, 本研究に携わつた学生諸君に深く感謝し ます．また，本研究は科学研究費補助金により実施 しました。この場を借りて厚く御礼申し上げます。

利益相反＼cjkstart開示すべき利益相反はない.

\section{REFERENCES}

1) Thom S. R., Compr. Physiol., 1, 421-446 (2011).

2) Verma A., Hirsch D. J., Glatt C. E., Ronnett G. V., Snyder S. H., Science, 259, 381-384 (1993).

3) Taguchi K., Maruyama T., Otagiri M., Curr. Med. Chem., doi: 10.2174/0929867325666181 113122340 (2018)

4) Ogaki S., Taguchi K., Watanabe H., Ishima Y., Otagiri M., Maruyama T., J. Pharm. Sci., 103, 2199-2206 (2014).

5) Allan P. F., Bloom B. B., Wanek S., Mil. Med., 176, 332-335 (2011).

6) Ozaki K. S., Kimura S., Murase N., Transplant. Rev. (Orlando), 26, 125-139 (2012).

7) Origassa C. S. T., Câmara N. O. S., World J. Hepatol., 5, 541 (2013).

8) Belcher J. D., Beckman J. D., Balla G., Balla J., Vercellotti G., Antioxid. Redox Signal., 12, 233-248 (2010).

9) Izuishi K., Wakabayashi H., Maeba T., Ryu M., Maeta H., World J. Surg., 24, 49-52; discussion 53 (2000).

10) Nakao A., Faleo G., Shimizu H., Nakahira K., Kohmoto J., Sugimoto R., Choi A. M. K., McCurry K. R., Takahashi T., Murase N., Kidney Int., 74, 1009-1016 (2008).

11) Ogaki S., Taguchi K., Maeda H., Watanabe H., Ishima Y., Otagiri M., Maruyama T., Biochem. Pharmacol., 97, 310-319 (2015).

12) Ogaki S., Taguchi K., Watanabe H., Otagiri M., Maruyama T., Drug Metab. Dispos., 41, 141-148 (2013).

13) Nagao S., Taguchi K., Sakai H., Tanaka R., Horinouchi H., Watanabe H., Kobayashi K., Otagiri M., Maruyama T., Biomaterials, 35, 6553-6562 (2014).

14) Sakai H., J. Funct. Biomater., 8, 10 (2017). 
15) Sakai H., Sou K., Horinouchi H., Kobayashi K., Tsuchida E., Artif. Organs, 33, 139-145 (2009).

16) Taguchi K., Yamasaki K., Sakai H., Maruyama T., Otagiri M., J. Pharm. Sci., 106, 23922400 (2017).

17) Amara N., Goven D., Prost F., Muloway R., Crestani B., Boczkowski J., Thorax, 65, 733738 (2010).

18) Hecker L., Vittal R., Jones T., Jagirdar R., Luckhardt T. R., Horowitz J. C., Pennathur S., Martinez F. J., Thannickal V. J., Nat. Med., 15, 1077-1081 (2009).

19) Lyle A. N., Deshpande N. N., Taniyama Y., Seidel-Rogol B., Pounkova L., Du P., Papaharalambus C., Lassègue B., Griendling K. K., Circ. Res., 105, 249-259 (2009) .

20) Taguchi K., Yamasaki K., Maruyama T., Otagiri M., J. Funct. Biomater., 8, 11 (2017).

21) Keipert P. E., Adv. Exp. Med. Biol., 977, 343-350 (2017).

22) Haruki R., Kimura T., Iwasaki H., Yamada K., Kamiyama I., Kohno M., Taguchi K., Nagao S., Maruyama T., Otagiri M., Komatsu T., Sci. Rep., 5, 12778 (2015).

23) Lok C., Nature, 410, 855 (2001).

24) Gekka M., Abumiya T., Komatsu T., Funaki R., Kurisu K., Shimbo D., Kawabori M., Osanai T., Nakayama N., Kazumata K., Houkin K., Stroke, 49, 1960-1968 (2018) .

25) García-Ruiz J. M., Galán-Arriola C., Fernández-Jiménez R., Aguero J., Sánchez-González
J., García-Alvarez A., Nuno-Ayala M., Dubé G. P., Zafirelis Z., López-Martín G. J., Bernal J. A., Lara-Pezzi E., Fuster V., Ibáñez B., Basic Res. Cardiol., 112, 17 (2017).

26) Gundersen S. I., Palmer A. F., Biotechnol. Prog., 24, 1353-1364 (2008).

27) Li H., Ohta H., Tahara Y., Nakamura S., Taguchi K., Nakagawa M., Oishi Y., Goto Y., Wada K., Kaga M., Inagaki M., Otagiri M., Yokota H., Shibata S., Sakai H., Okamura K., Yaegashi N., Sci. Rep., 5, 15271 (2015) .

28) Nagao S., Taguchi K., Miyazaki Y., Wakayama T., Chuang V. T. G., Yamasaki K., Watanabe H., Sakai H., Otagiri M., Maruyama T., J. Control. Release, 234, 49-58 (2016) .

29) Taguchi K., Nagao S., Maeda H., Yanagisawa H., Sakai H., Yamasaki K., Wakayama T., Watanabe H., Otagiri M., Maruyama T., Drug Deliv., 25, 1266-1274 (2018).

30) Nagao S., Taguchi K., Sakai H., Yamasaki K., Watanabe H., Otagiri M., Maruyama T., Int. J. Nanomedicine, 11, 5611-5620 (2016) .

31) Brotman I., Kocher M., McHugh S., $A \& A$ Pract., 12, 243-245 (2019).

32) Abu Jawdeh B. G., Woodle E. S., Leino A. D., Brailey P., Tremblay S., Dorst T., Abdallah M. H., Govil A., Byczkowski D., Misra H., Abuchowski A., Alloway R. R., Clin. Transplant., 32, e13155 (2018).

33) Jia L., Bonaventura C., Bonaventura J., Stamler J. S., Nature, 380, 221-226 (1996) . 